\title{
Ethno-Linguistic Distribution of Anthroponyms in the Name System of Multinational Region
}

Olga N. Novikova, ${ }^{+*}$ Rakhim Z. Muryasov, ${ }^{\dagger}$ Alfiya F. Aznabaeva, ${ }^{i}$ Andrey N. Belyaev, ${ }^{\ddagger}$ Yuliya V. Kalugina, '́ Albina R. Mustafina, ${ }^{\tilde{i}}$ Tatyana V. Shpar, ${ }^{\beta}$ Tatiana N. Taletskaya, ${ }^{\zeta}$ and Zilya R. Khazhieva ${ }^{i}$

\section{Abstract}

The purpose of the study is to examine the ethnolinguistic distribution of anthroponymic models in the multinational Republic of Bashkortostan. The authors consider the linguistic features of proper names taking into account the system capabilities of the analysed languages in the areas of language and cultural interaction. Six thousand anthroponymic units of living names of four nationalities of the region under study (Russians, Bashkirs, Germans and Latvians) were analysed. Ethno-linguistic affiliation in the anthroponymic formula of each nationality is revealed through a comprehensive analysis of proper names. Ethnically marked proper names within the framework of the corresponding system of a given language are characterised by increased distinctive ability in various communicative situations. Results show that there is no robust and direct connection between the ethnic characteristics of the first name and the nominator's ethnic identity. With that, the name as an information source in the study of human identity allows the researchers to draw certain conclusions, as the name is the result of the choice made to reach a certain goal. It enables the actual means used to be correlated with a variety of other possible means, which makes it possible to compare socially important knowledge, shared by everyone, with individual aspects of the general. The results of this research can be useful in the practice of naming children born in exogamous marriages as well as in describing the onomastic situation in countries with a large influx of migrants.

Keywords: Onomastics, Anthroponym, Anthroponymicon, Multi-Ethnic Region, Ethno-Lingual Marker, Given Name, Surname, Patronymic, Ethnolinguistic Distribution, Ethnic Identity

\footnotetext{
+ Doctor of Philological Sciences, Associate Professor, Head of the department, Federal State Budgetary Educational Establishment of Higher Education Bashkir State Agrarian University, 34 50-letiya Oktyabrya St., 450001, Ufa, Russia *Corresponding Author, Email: nowikowa.0lha@gmail.com, novikova58@bk.ru

i Doctor of Philological Sciences, Professor, Federal State Budgetary Educational Establishment of Higher Education Bashkir State University, y, 34 50-letiya Oktyabrya St., 450001, Ufa, Russia, Email: kafedra22@mail.ru

$\hat{\imath}$ Candidate of Philological Sciences, Associate Professor, Federal State Budgetary Educational Establishment of Higher Education Bashkir State Agrarian University, y, 34 50-letiya Oktyabrya St., 450001, Ufa, Russia, Email: pjatashok@yandex.ru

$¥$ Doctor of Philological Sciences, Associate Professor, Federal State Budgetary Educational Establishment of Higher Education Bashkir State Agrarian University, y, 34 50-letiya Oktyabrya St., 450001, Ufa, Russia, Email: anbelajew@mail.ru

I Candidate of Philological Sciences, Associate Professor, Federal State Budgetary Educational Establishment of Higher Education Bashkir State Agrarian University, y, 34 50-letiya Oktyabrya St., 450001, Ufa, Russia, Email: yu.v.kalugina@gmail.com

¿ Candidate of Philological Sciences, Senior Lecturer, Federal State Budgetary Educational Establishment of Higher Education Bashkir State Agrarian University, y, 34 50-letiya Oktyabrya St., 450001, Ufa, Russia, Email: alb344@yandex.ru

$\beta$ Candidate of Philological Sciences, Senior Lecturer, Federal State Budgetary Educational Establishment of Higher Education Bashkir State Agrarian University, y, 34 50-letiya Oktyabrya St., 450001, Ufa, Russia, Email: tatsch-tat@yandex.ru

'Candidate of Philological Sciences, Associate Professor, Educational Establishment «Mozyr State Pedagogical University named after I.P.Shamyakin», 28/1 Studencheskaya St., 247760, Mozyr, Republic of Belarus, Email: tatjanatalezkaya@mail.ru

'Candidate of Philological Sciences, Associate Professor, Federal State Budgetary Educational Establishment of Higher Education Bashkir State Agrarian University, y, 34 50-letiya Oktyabrya St., 450001, Ufa, Russia, Email: khazhieva_zr@mail.ru

(C) 2019 Novikova et al. This is an Open Access article distributed under the terms of the Creative Commons Attribution License (http://creativecommons.org/licenses/by/2.0), which permits unrestricted use, distribution, and reproduction in any medium, provided the original work is properly cited.
} 


\section{Introduction}

Today, proper names are generally regarded as signs of culture, national and ethno-lingual identity. Therefore, they are actively used to describe and reconstruct the development of society (Aceto, 2002; Mateos, 2007; 2014; Hofmann \& Mueller, 2016; Gaddis, 2017; Bailey \& Lie, 2017). The study of national anthroponymicon in the areas of ethnic, confessional, and cultural mixing is especially productive in this aspect (Shcherbak, 2016; Shkuropatskaya \& Davaa, 2016; Pustyakov, 2017).

The issues of studying the relationship between language and national culture are so prevalent in modern linguistic science that they claim a principal leading place in the list of its underlying problems; the statement of this fact has become an inevitable common-place and a traditional "beginning" of many newly emerging linguistic studies (Risager, 2006). The relationship between language and culture is interpreted variously - as interreflection \{cf. set phrases language in the mirror of culture and culture in the mirror of language (Deutscher, 2010)\}, diffusion \{culturally loaded vocabulary, cultural connotation, cultural semantics, etc. (Wierzbicka, 2012)\}, mutual translation \{languages of the culture (Virgilio, 2002)\}. Approaches to the study of language - culture correlation are mastered by different linguistic disciplines, while there is no doubt that the most important role among them should belong to ethnolinguistics (Aceto, 2002).

A promising prospect for the study of the anthroponymicon of the multi-ethnic region is its consideration in the cognitive aspect as the interaction of the anthroponymic concept with the dialect (Shcherbak, 2014).

The key objective of this research is anthroponyms - given names, patronymics and surnames - as the official naming of the individual; the subject is the processes taking place in the anthroponymicon of the Republic of Bashkortostan (RB, Bashkortostan). The qualitative processes characterising the state of the modern anthroponymicon of the poly-ethnic and multicultural region of Russia are considered in the context of the idea about the mutual influence of language, culture and society. The relevance of the analysis of their interaction today can be explained by a number of reasons: the necessity of accounting for the general and specific characteristics of different peoples and defining their cultural values (Gerhards, 2005); the trend towards the integration of the Humanities, which determined the interest of linguists in related subject area (Kolylhalov \& Pushkareva, 2018); the emergence of anthropocentric trend in linguistics (Labashchuk, 2015); understanding the language as a means of conceptualising knowledge and ideas about the world and the accumulator of cultural values (Wierzbicka, 2012). The most conservative layer of onyms - Russian anthroponymy, reveals the signs of the new time against the background of multiple lexical innovations (Golomidova, 2005).

Describing the state of the Russian list of names in the Soviet period, the following features can be distinguished: full dechristianisation of the list of names, both in its ideological sound and specific naming practice (explanation of the name choice); out-of-line nature of its implementation; reduced distinctions between the list of urban and rural names; processes of onomastic transformations, manifested in the creation of new names, in their bold borrowing, the rejection of some names; active antroponymy interaction of different nations. All the features are considered with regard to modern history, revealing the transformations in the naming practice when changing the social and cultural background (Golomidova, 2005). The processes studied are a deepening of the earlier changes and affect different countries to a different extent (see the naming trends: in Spain C. Luján-García (2015), in Germany - J. Gerhards (2005), in the USA - S. Lieberson (1992). The researchers take the position that the macro-cultural realities of today's world individualisation and globalisation - are reflected in the micro-phenomenon of the given 
name (Gerhards, 2005; Gerritzen, 2006; Kandt \& Longley, 2018).

In the context of our research, the dialectic of the individual and the universal (global) is that due to social progress - the global trend of social development - individuals have more opportunities, rights and freedoms. The scope of the naming and the attitude of the language group members to the names are not an exception. A given name is not just an identifying mark, it contains linguistic, ethnic, cultural, religious, family, gender information about the carrier of the name. There are unique name systems in different parts of the world, but in the era of globalisation, the need of individuals for self-identity is often lost - people have the right not to manifest their belonging to the ethnolinguistic community. On the other hand, even the most unusual, rare name (for example, Landysh, 'Lily of the Valley') can perform an identifying function and serve as a distinctive sign since its significant component is negligible. While interacting with the world, the given name is perceived as the personal name of the individual. The background knowledge that representatives of different linguocultural communities have allowed them to recognise the "naming base" as their own national variant among other national invariants. Cf: Ivan (Russian) - Johann (German) - Juan (Spanish, Port.) - John (English) - Giovanni (Italian) Janusz (Polish) - Jean (French). However, in the context of multinationality anthroponymic studies have their own specifics. We consider multinationality as a group of people belonging to different cultural and historical communities, speaking different languages, sometimes belonging to different religious groups, but living in a specific territory, characterised by the unity of foreign and national policies and close economic ties. In the multinational subject of the Russian Federation, the Republic of Bashkortostan, idioethnic, all-Russian and global naming tendencies are interrelated.

The history and current state of the official naming of an individual in Russia show the qualitative variability of the anthroponymic formula itself, the differences in the distribution of its components by time and geographical parameters, the influence of Russian anthroponymy (both anthroponymic formula and the qualitative composition of the onyms).

The purpose of this research is to give qualitative and quantitative characteristics of the anthroponymicon of the multi-ethnic region of Russia through a synchronous analysis of the observed processes.

A review of studies performed within the framework of linguistic and cognitive and linguistic and cultural approaches to the study of the given name phenomenon has led to the conclusion that idio-ethnic (national) and universal (supranational) cultural dominants reflect the anthroponymicon specifics of the region under analysis.

To describe the processes of borrowing and assimilating names in a foreign language environment, as well as to identify factors affecting changes in the given name system of the representatives of the Slavic, Germanic, Baltic groups of Indo-European language family living on the territory of the Republic of Bashkortostan - a region densely populated by Bashkirs (the Turkic group of the Altai language family) - the following steps were taken:

- comprehensive analysis of the living names - of students of Bashkir State Agrarian University and the names recorded in the latest reference books;

- statistic data analysis of the ethnic composition of the Republic of Bashkortostan;

- oral survey data processing.

We have revealed the explicit and implicit properties of the anthroponym that allowed us to get results (Table 1) and come to a conclusion: a given name possesses the ontologically inherent feature to act as a marker of identity. However, there can be no link between the ethno-characterisation of the name and the individual's ethnic identity in multicultural, multilingual anthroponymic environment. The materials and methods deployed for this research are discussed in the next section. 


\section{Materials and Methods}

The research has been performed on the statistics on quantitative and qualitative composition of RB anthroponymicon for 20012018; dictionaries of Bashkir (Tupeev, 2010), German, Russian personal names and surnames (Superanskaya, 2006); data on full naming of 3,200 extramural students of Bashkir State Agrarian University (for 2015-2018). All of them are residents of the Republic of Bashkortostan, aged 17 to 40 . To preserve confidentiality, the research intentionally does not disclose the full names. The field data obtained in Blagovarsky and Arkhangelsky regions of the Republic in 2015-2018 through an oral survey of informants were used.

To solve the tasks, the following interrelated methods were used at different stages of the research:

- Descriptive method. It gave an idea about the anthroponymic system on the basis of observing its functioning in synchrony, the qualitative characteristics of the onyms under study, and ethnolingual markers; allowed to identify the factors determining such parameters as stability and dynamics, degree of openness of ethnic anthropystems, global and idio-ethnic trends in the anthroponymicon development.

- Statistical. This method was used to obtain, process and analyse the information about the anthroponyms, which allowed to quantify the patterns of their existence; the research material consists of the data on the ethnic composition of the multi-ethnic region in question - the Republic of Bashkortostan (results of 2010 Russian population census), 7,500 Russian names (Superanskaya, 2006); 3,000 Bashkir personal names (Tupeev, 2010), German personal names; 3,200 names of extamural students of Bashkir State Agrarian University, 43 units of Latvian anthroponyms, 28 units of German anthroponyms selected by targeted result sampling of an oral survey of informants; as well as 2,350 personal names obtained in the course of processing 115,000 birth records of the registry office archive of the Republic of Bashkortostan

- Structural analysis. It allowed identifying onymic models and lexemes and affixes that fill them, to reveal the way they were formed (affixation, compounding, hybridization, juxtaposition).

- Comparative. This method made it possible to find common and distinctive features peculiar to different languages through thematic and semantic analysis of the units under study. Types and models of anthroponymic nomination, semantic models of names, the semantics of reproducing word-stem are subject to comparison.

Although the research is conducted in the synchronic aspect, sometimes it is necessary to refer to history to compare anthroponymic models in diachrony and to establish the correlation of onomastic phenomena with certain periods of society.

- Historical - to determine the onomastic formations by language, in particular, when analysing the qualitative changes in the anthroponymy of ethnic Germans, Latvians living in the Republic of Bashkortostan;

Thus, the integrative use of these methods makes it possible to distinguish onomastic formations according to the following criteria: the method of name formation, the chronology of its appearance, name structure, the semantics of the word-stem. The findings of the research are discussed in the following sections.

\section{Results and Discussions}

National anthroponymicon is a complex system that combines several subsystems built on the word-formation, semantic or communicative principle.

According to the data of the Federal State Statistics Service based on Russian Census 2010, there are representatives of 160 nationalities including 13 ethnic groups on the territory of the Republic of Bashkortostan (Results of 2010 
Russian Population Census in the Republic of Bashkortostan).

The majority of families in the Republic are mono-national. There are more nationally homogeneous marriages in the village than in the city. Russians dominate urban endogamous marriages. In exogamous marriages, the share of Bashkir-Tatar marriages is high, which is primarily determined by the affinity of many cultural and domestic traditions, the religion of these ethnic groups and the proximity of their languages. The lists of names of all nations are systems, including anthroponyms that genetically date back to different languages.

Rating of baby names in the Republic of Bashkortostan for the period from 2011 to 2018 indicates the relatively stable popularity of boy names Artyom, Timur, Kirill, Amir, Danil and girl names - Arina, Sofiya / Sof'ya, Samira, Viktoriya, Anastasiya. By the way, originally rare female name Samira (in 2011), today included in the shortlist of popular names, was not recorded in earlier dictionaries of Bashkir names.

In endogamous marriages "Russian/Russian", the preference is given to traditional personal names (Aznabaeva, 2006). Similarly, in endogamous marriages "Bashkir/Bashkir", "Tatar/Tatar", Turkic names of Arabic and Persian origin experience fierce competition from numerous borrowed (mastered) and fantasy names (Aznabaeva, 2006). In general, the author positively assesses the rejection of dissonant names despite still dominant meaningful criterion in the naming processes of modern Turkic-speaking ethnic society and notes the readiness of Bashkir anthroponymicon to integrate into the global anthroponymic system. However, most researchers of modern national anthroponymicons give a negative assessment of the name borrowing in any form, considering it disrespectful to their people, language and culture. The naming by borrowed names is regarded as a result of speech community passivity leading to destructive consequences: speech "clogging", communication complexity, value displacement, and destruction of the national consciousness (see, for example, Tupeev S.Kh. (2010)).
However, even in this edition, the names of Spanish, French, German origin are indicated. For example, male names Artur and Robert. These two male names are included in all dictionaries of Bashkir names. Thus, the issue is the degree of name development. G.R. Galiullina identifies three directions of modern Tatar anthroponymicon development: continuation of the ancient Turkic tradition; a tradition that came into the national consciousness of the people along with Islam; Russian and European traditions (Galiullina, 2002).

In 2010, there were nine most numerous nationalities in the Republic of Bashkortostan. Of these, three nationalities (Russians, Bashkirs and Tatars) accounted for $90 \%$ of the Republic population (more than 3.6 million people) (Results of 2010 Russian population census in the Republic of Bashkortostan). Small ethnic groups are often dissolved in a foreign-language environment, but ethnic Germans (one of the most numerous nations in Europe), being longtime settlers in the Republic of Bashkortostan, not only saved their ethnic identity but also had an impact on local anthroponymy. Such fairly frequent onyms as German, Artur, Rudol'f acknowledge the facts of the popularity of German names among Bashkirs and Tatars.

Let us now turn to the analysis of personal names taken from the Germans living in the territory of the Republic of Bashkortostan (the island Diaspora, which is the specificity of the region).

According to the 2010 Russian Population Census, the number of Germans in the Republic was 5,909 people. The first German settlers served in the Ufa garrison as early as the 17th century. Various historical events (Stolypin agrarian reform, the deportation of Germans from the liquidated Republic of the Volga Germans and others) contributed to the subsequent influx of Germans into the territory of Bashkortostan.

In a compact environment, the German population maintained its cultural traditions and language, which was also expressed in the names given to their children. Thus, such personal names as Vil'gel'm, Rudol'f, Vanda, 
Gil'da, Georg, Karl, Fridrikh, Gergard and others testify to belonging to the German ethnic group. In accordance with the Russian tradition of giving a person a surname, name and patronymic the Germans in Russia, in addition to family and personal name, are also endowed with father's name: Doroteya Abramovna, Rayngol'd Genrikhovich, Agata Osval'dovna, Genrikh Gergardovich, Teodor Teodorovich, Ida Arnol'dovna, Garri Reyngol'dovich. Compliance of all three components - surname, given name, and patronymic - to the German national list of names is clearly in evidence at inhabitants of German settlements in Bashkiria up to 1941.

Children born after the beginning of the Great Patriotic War and in the postwar period more often assume names from the Russian anthroponymicon. There are combinations of "Russian given name + patronymic" derived from the name of the German list of names: Nina Karlovna, Nina Oskarovna, Lidiya Yeval'dovna, Nadezhda Reyngol'dovna, Liliya Vol'demarovna, Irina Yernstovna, Konstantin Rudol'fovich.

At the present stage of development of anthroponymicon of Russian Germans living in the territory of Bashkortostan, the combination "Russian given name + Russian patronymic" predominates Elena Vasil'evna, Vladimir Viktorovich, Igor' Ivanovich, Tat'yana Evgen'evna, Veronika Dmitrievna, Elena Aleksandrovna.

Thus, the name and patronymic cease to be a marker indicating the ethnicity of the individual. The use of Russian names for ethnic Germans over the past two or three generations levels the onomastic determinancy unifies the named fund of the residents of the multi-national Republic. In our opinion, this process was influenced by a number of factors:

- Historical: the World Wars of the first half of the 20th Century dealt a crushing blow to the image of Germans, everything German was taken extremely negatively. The tendency to use Russian anthroponyms for naming children in Russian German families was intended to disguise ethnic origin in order to alleviate and smooth out the life difficulties that could arise on the basis of national enmity.

- Social: living in "foreign" territory, small national groups are influenced by culture, mentality, the social organisation of larger nationalities, as well as other ethnic groups in the same territory. The Germans assimilated with the local population, adopting, among other things, its naming system. The Russian anthroponymicon was the most appropriate, as part of the personal names refers to international onyms recorded in both Russian and German lists of names: Anna, Aleksandr, Roza, Anton. Some personal names are of the same origin but may differ slightly in form: Nikolay - Nickolaus, Pyotr - Peter, Ivan - Johann, Yakov - Jacob, Elena Helen.

- Linguistic: since the Russian language had the status of the state language, there is no doubt that the language realities of the Russian language had a huge impact on the entire area of Russia. Naturally, that hard to pronounce Vil'gel'm, Gergard, Aaron, Gertruda were replaced by the usual Nina, Ivan.

- Onomastic: naming is subject to the vagaries of fashion for names. Each time period is characterised by certain personal onyms, which are most popular among the population. Perhaps, such names as Korneliy or Gotlib, Yerna or Irma became antiquated at some time. Other, more modern ones replaced them.

Thus, the following trends in the development of German anthroponymicon in Bashkortostan can be distinguished: assimilation with Russian anthroponymicon, the disappearance of indigenous German given names, simplification, a narrowing of their range.

Let us turn to the representatives of another nationality - Latvian. This layer of proper names is of great importance for us, since the study of island Latvian anthroponymy can provide the key to understanding several issues that go far 
beyond its periphery. It should be emphasised that Latvian surnames represent one of the newest layers of the Latvian name system and the process of its formation is still historically visible. The Latvians appeared in the territory of Bashkortostan in the 70s of the 19th Century. Most of the settlers were rural immigrants from the Governorates of Courland and Livonia. By 1887, there were 385 Latvian farms with 3,875 residents in Ufa Governorate. The next stage of the resettlement of Latvians to Bashkiria is associated with the Stolypin agrarian reform. By 1920, their number in Bashkiria reached the maximum level $-8,128$ people, in 1928 there were 25 Latvian colonies. The largest of them were on the territory of Ufa Canton: Austrum, Ozolyi, Baltiya, Balozhi and Arkhangelskoe villages. Since the mid-20th Century, Latvians began to return to Latvia, mainly the younger generation, striving to preserve the national language, traditions and culture.

Latvian surnames did not arise "naturally" (due to the long-term name growth into surnames) but somewhat artificially as the one-time implementation of the legal decree. It happened at the beginning of the 20th Century. Until that time Latvian peasants, as a rule, were called by name and the name of the farm or village. On this basis, it can be assumed that Latvian peasants already had surnames on arrival in Bashkiria. Among Latvians living in the Republic of Bashkortostan such names as Verner Yuriy Zhanovich, Ena Lyudmila, Zvere Robert Yanovich, Zil'berg Ayna, Lisman, Yan, Miller Yemma, Pappe Mariya Yernestovna, Rinkman Robert, Rudzit Valeriy, Rudzit Al'fon, Tyille Anatoliy, Treze Andrey, Tsirul' Vilis Yanovich, Yuppe Gennadiy, Yegit Yan, Balod, Yan, Brandt Yemma, Gibet Nadezhda, Carklin Zhan, Pets Ol'ga, Rozit, Yunder Yan, Freyman Neliya, Beyzbol Tamara, Vasserman, Gaylis, Zvaygzne Yemma, Tsirul' Irina, Bets Ol'ga, Vol'berg Yelmar, Knoyes Vera, Zvaygzne Neliya, Miskaktina Svetlana, Bozhe Yan, Olin Dzhon, Roste Zedon, Zalkind Anna, Miller Milda, Miskaktin Yan Yur'evich, Absen Eduard, Zvirbul Arvid, Zarin' Aleks are common.

According to G.H. Shenkao (2002), openness to innovations contributes to the improvement of adaptive abilities of the ethnic group. On the other hand, high variability leads to the erosion of ethnic identity and loss of self-identification guidelines (Shenkao, 2002). "Changes in the naming system may not be recorded in the mass consciousness, remaining within the framework of natural scientific anthropological and ethnographic data, but they are the first symptoms of changes in the mythosymbolic system of the given culture in new patterns of cultural and linguistic communication. Each community, whose members are alive in the cultural sense and have a chance for cultural development, always perform the function of transforming the existing anthroponymic system ..." (Tarasov, 2007: 101). Each new name reduces the number of old ones; new anthroponymy is not stable, nominative units with a unique reference tend to quickly fall out of the naming system if the linguistic and cultural community loses interest in the referent. At the same time, one should not forget that the identification of words of foreign origin in the vocabulary of any literary language poses a significant difficulty associated with the factors of theoretical, historical, etymological and methodological nature. Indeed, the name system of any nation is an open, developing system. Most of the "Russian" names came from Hebrew, Greek, Latin.

Oral surveys showed that mixed names are common not only in mixed marriages, where they stand as a compromise to preserve both paternal and maternal lines, cf.: Ul'yana Fandilova, Galina Ramilevna, Greta Nikolaevna, Raushan Borisovich. When the bearer of such a name changes her/his surname, for example, in marriage, from the Turkic to another or vice versa, the name characteristics such as "ethnicity", "religious identity" will become even vaguer. This begs the question about the place of name-giving process in the structure of selfidentification; in this case, of the nominator's identity: a person gives a name to another, which the latter bears all his life and on which, to some extent, the names of descendants will depend. 
Quantitative analysis shows the highest internalisation of masculine given names Ruslan, Vadim, and Artur, Albert, Marat, Robert, Eduard and feminine given names Yulia, Svetlana, Irina, which match neither non-Russian nor Russian patronymic names, cf.: Vadim Gafurovich, Fasikhovich, II'mirovich, Al'firovich, Venerovich, Alexandrovich, Valer'evich, Vladislavovich, Arturovich; Svetlana Ramilevna, Ildusovna, Airatovna, Vladimirovna, Ivanovna, Borisovna. These names can be considered as assimilated: they have been used with high frequency for decades and recorded in the dictionaries of Bashkir and Tatar given names. The frequent use in patronymic names confirms their longstanding popularity, cf.: Aynur Al'bertovich, Eleonora Al'bertovna, Ilya Maratovich, Rusalina Maratovna, Amir Eduardovich, Gennadiy Robertovich, Gul'fiya Robertovna. The names are found in different graphic forms, which are rightfully independent full names, cf.: Vener / Viner, Ferdinand / Ferdinant, Al'fred / Al'fret / Al'frit / Ol'fred. In the regions where several ethnic groups live, scholars reveal the dichotomy of ancestral names and their substitutes in an environment with a dominant state language. In the multiethnic space, people of small ethnic groups use "their" own names different from the official ones in communication (Aceto, 2002). The presence of numerous friendly ethnic groups in Bashkortostan living together for centuries could not but lead to a similar phenomenon, cf.: Gul'fia $>$ Galya, Fidan > Fedya. The replacement is common in daily life; however, the statistical analysis indicates an increase in shorter forms of names given at birth: Lena, Alik, Vladik, Rita, Alyena.

In the modern dictionary of Bashkir given names and surnames (Suleymanova, 2013) the name Rudol'f meaning "wolf of glory" in German has no mark of "neologism". This raises the question of what the anthroponymic neologism stands for. The question is relevant as neulogical anthroponyms are studied randomly, mainly within the framework of the idiostyle of an individual writer or a term system; today there is neither definition of this concept, nor construction of "anthroponym-neologism". Both foreign language borrowings, fantasy names and variants of existing names fall into the category of the "new" vocabulary, that is, the plane of expression is considered in the first place.

In this regard an interesting feature is the generation of etymological alternatives-onyms that came from the same source, but received their own pronunciation and spelling in different languages in accordance with the phonetic and graphic traditions: $A \lambda \dot{\varepsilon} \xi \alpha v \delta \rho \circ \varsigma$ (Ancient Greek

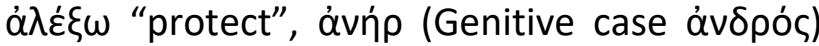
"man"), Aleksandr (Russian), Iskandar (Bashkir), Alehandro (Spanish), Alexander (German) and so on. Cognitive behaviour is typical of a human; that is, he is interested in what his/ her first name means. As it is common for a dictionary to specify the origin of a name, it must be recorded in full, cf.: the dictionary compiled by R. A. Suleymanova considers the neologism Yuris as derived from the word 'jurist' (Suleymanova, 2013). We cannot deny this possibility (of the people's creative onomastic potential in the Republic of Bashkortostan, ref.: (Timirkhanov, 2006)), still, there is a good reason to point to another possible source of the name - from the Latvian language (derived from jứre - "sea"). An argument to support this view is a great number of people bearing this name and Latvian settlements found in Bashkortostan. Although the masculine name Vildan is transparent in its etymology: it traces its origin to the Arabic "child, son; servant in paradise", the transliterated onomastic variant Vil'dan is, probably, associated with the practice to transliterate quasi - phoneme $(*)$, denoted by [b] or [b] in the Russian language, which does not possess any graphic character in Turkic languages (similarly to the common Bashkir and Tatar female name Гөлнара (Gulnara) derived from the Persian гөл (Gul) "flower", and transliterated into Russian as Gul'nara). However, phonetically and in spelling, the name coincides with a neulogism, translated literally from the Bashkir language as "Glory to Vladimir Ilyich Lenin!" formed by the fusion of the abbreviation of Vladimir Ilyich Lenin and the word dan meaning "glory" in the Bashkir language. However, the name Vil'dan may be a transliteration variant of Bashkir male name 
Uyildan (from the river Uyiil). The hiatuses yo, uii, ay typical of the Bashkir language are unusual and difficult to pronounce for Russian native speakers, so they are usually transliterated with the graphemes of the Russian language, corresponding to yotized vowels: Йомабика (Yomabike) - Yumabika (Arabic Yoma "Friday" + Arabic Bika "hostess"). The feminine name Gaukhar (Persian "the pearl") has two graphics versions in Russian: Gaukhar and Gavgar - however, euphonically the first version is preferable. On the other hand, why have the transliterated into Russian onyms Uayld (Oscar Fingal O'flahertie Wills Wilde), Uolt (Walter Elias Disney who had Germans among his ancestors and the version Valter would be rightful), Uillis (Walter Bruce Willis) retained hiatus in writing, and the name Valter Skott (Walter Scott) has not? The lack of uniformity in spelling can be explained by the contradiction between the foreign phonetic and spelling characteristics of a word and its Russian phonetic and graphic adaptation. Originally, the draft law signed on 01 May 2017 by the President of the Russian Federation V. V. Putin "on amendments to article 58 of the Family code of the Russian Federation and article 18 of the Federal law "on acts of civil status" according to which no figures, alphanumeric characters, numerals, symbols and non-letter signs except for the hyphen sign, or any combinations of the characters or swear words, references to ranks, positions, titles are allowed, contained prohibition on the names representing abbreviations. But according to the Tatarstan Directorate for Registry Offices, the name of Damir (Daesh' mirovuyu revolyutsiyu meaning the slogan 'The world revolution now!') has been given to 1857 children in the republic of Tatarstan for 10 years. First names denoting abbreviations Vil (Vladimir Ilyich Lenin), Vilen (Vladimir llyich Lenin) came into common use after the Russian October revolution in the 1920s, and names Vilena, Lenara (Lenin's army) which are quite frequent at present are hardly associated with revolutionary sentiments, and are taken as national Tatar and Bashkir first names (Arguments and Facts, 2017). Members of the State Assembly of the Republic of
Bashkortostan (Kurultai) voiced the concern first expressed by members of Tatarstan's parliament about the names that fall under the prohibition. The case was about the names of Amir / Emir (Arabic امير - "the Prince", meaning the title of a ruler and generally the person that bears this title in a number of Muslim countries of the East and Africa (the name Amir is among the most popular names for boys in the Republic of Bashkortostan for 2015, 2016, 2017) and Sultan (Arabic שולטנא sulțān, Aramaic שול suanā "power") meaning the title of a ruler in the Islamic States) which are taken as names, not as titles in everyday perception. Apostrophes and stress characters are also prohibited. The question of how to deal with surnames such as O'nil, Semenov, Osintsev, Kovalev is becoming rather relevant.

The full passport name of the citizen of the Russian Federation consists of a surname, a first name and a patronymic. This may lead to the question of how to avoid embarrassment in the situation of speech etiquette because there is particular energy inherent in the anthroponymic sequence "Surname - First name - Patronymic". Moreover, the use of patronymic may not be considered absurd and unnecessary: to hear Vladimir is one thing and quite another Vladimir Volfovich - on hearing it the image of the politician comes instantly into view, without mentioning his surname. The Russian legislation will undoubtedly change in the context of naming (the issue of putting the letter ë in toponyms (place names) has been resolved positively). The last amendment was made because of the adverse reaction of the absolute majority of the Russian language society to the "strange" names: Tsar' or Korol' meaning "King", Lyubimitsa-Krasavitsa-Umnitsa meaning "Darling-Beauty-Smartie".

The reference to the surname derived from the first name brings us back to the question of the description of the onym in the anthroponymic dictionary. Can a name be considered a neologism if it was the basis for a surname? Cf.: a masculine first name Fayruz as a neologism of the Persian origin and the last name Fayruzov (Suleymanova, 2013). 
Table 1: Determinants of ethno-lingual distribution of anthroponyms in the Republic of Bashkortostan The pursuit of keeping the ethnic identity in endogamous marriages through ethnically identified first names, for instance:

\begin{tabular}{|c|c|c|}
\hline - & Russians & $\begin{array}{l}\text { feminine: Miroslava, Lyudmila } \\
\text { masculine: Yaroslav, Vladislav }\end{array}$ \\
\hline - & Greeks & $\begin{array}{l}\text { feminine: Ellada, Afina } \\
\text { masculine: Andrianik, Dionis }\end{array}$ \\
\hline - & Tadjiks & $\begin{array}{l}\text { feminine: Zebo, Dil’noza } \\
\text { masculine: Sherali }\end{array}$ \\
\hline - & Vietnamese & $\begin{array}{l}\text { feminine: } M i \\
\text { masculine: Tkhi, Van }\end{array}$ \\
\hline - & Gypsies & $\begin{array}{l}\text { feminine: Zita } \\
\text { masculine: Budulay }\end{array}$ \\
\hline - & Germans & $\begin{array}{l}\text { feminine: Gertruda } \\
\text { masculine: Arnol'd }\end{array}$ \\
\hline - & Georgians & $\begin{array}{l}\text { feminine: Nana } \\
\text { masculine: Mamuka }\end{array}$ \\
\hline - & Kurds & $\begin{array}{l}\text { feminine: Yasmin } \\
\text { masculine: Zhamel' }\end{array}$ \\
\hline - & Azerbaijani & $\begin{array}{l}\text { feminine: Gyunay } \\
\text { masculine: Goshgar }\end{array}$ \\
\hline - & Avars & $\begin{array}{l}\text { feminine: Aminat } \\
\text { masculine: Gadgi }\end{array}$ \\
\hline
\end{tabular}

The trend toward giving old-fashioned first names (not frequent) as opposed to frequently used surnames (Abdullin, Ivanov)

\begin{tabular}{l|l}
\hline - & $\begin{array}{l}\text { masculine: Yulay, Ural, Aytugan } \\
\text { feminine: Syumbel', Gul'banu }\end{array}$ \\
\hline - & feminine: Serafima, Varvara \\
& masculine: Tikhon, Arkhip, Savva, Ermak \\
\hline
\end{tabular}

1. Compromise first names given in exogamous marriages borrowed from/ through Russian and causing no dissonance (assimilated)

\begin{tabular}{|c|c|}
\hline $\begin{array}{l}\text { Bashkirs and Russians } \\
\text { Tatars and Russians }\end{array}$ & $\begin{array}{l}\text { feminine: Liliya, Svetlana, Viktoriya, Karina, Elizaveta } \\
\text { masculine: Timur, Artur, Robert, Maksim, Roman, Dmitriy }\end{array}$ \\
\hline \multicolumn{2}{|l|}{ Originality (exclusiveness) } \\
\hline $\begin{array}{l}\text { Double first names (not } \\
\text { frequent). }\end{array}$ & $\begin{array}{l}\text { feminine: Alexandra-Emiliya, Alexandra-Amaliya } \\
\text { masculine: Ali-Zhan, Abdul-Kerim, Ruslan-Amal'. Mukhammad-Yazid } \\
\text { Mark-Yamach, Ernest-Tekin }\end{array}$ \\
\hline $\begin{array}{l}\text { Unassimilated first names of } \\
\text { western origin featuring consonant or } \\
\text { vocal endings not typical of the Russian } \\
\text { language }\end{array}$ & $\begin{array}{l}\text { feminine: Dominik, Nikol', Dzheyn, Ameli, Elizabet, Alize } \\
\text { masculine: Nikolas }\end{array}$ \\
\hline $\begin{array}{l}\text { Different stress in first names as } \\
\text { an effort to get rid of the name's "village } \\
\text { nature" }\end{array}$ & $\begin{array}{l}\text { feminine: Fatim`a / Fat`ima/F`atima; } \\
\text { Amin`a / Am`ina }\end{array}$ \\
\hline \multicolumn{2}{|c|}{ Variability: graphic and phonetic doublet character of onyms } \\
\hline $\begin{array}{l}\text { allographs } \\
\text { allophones }\end{array}$ & $\begin{array}{l}\text { feminine: Lyasan / Leysan /Lehysan } \\
\text { masculine: Rustam / Rustem / Rustehm }\end{array}$ \\
\hline
\end{tabular}

Short first name forms taken as official personal first names reflecting the global tendency toward language economy

\begin{tabular}{l|l}
\hline - dimunitives & $\begin{array}{l}\text { feminine: Lena, Rita, Lina, Aleksa } \\
\text { masculine: Alik, Zhora } \\
\text { masculine: Vil'; } \\
\text { Kim (unisex)) }\end{array}$
\end{tabular}


How significant is the time factor in the process of a neologism turning into one's "own" first name? At the point of the making, the new name is motivated and considered as the person's name by its nominator only; for society, it is "alien" and has to undergo socialisation - the stages of recognising it as a name, and its cognitive consolidation as a name. Theoretical comprehension of the particular questions should be linked with logic, psychology, philosophy (Muryasov, 2006) and must contribute to the development of the theory of the meaning of the proper name (anthroponym) in the light of the latest semantic theories.

The Republic of Bashkortostan is a multilingual region of the Russian Federation with historically developed tolerance to the ethnic groups concentrated on its territory for a long time, and to the ethnic groups, which entered the region as a result of migration inflows. The ambivalence about the current anthroponymic situation in the region lies in the eclectic coexistence of archaic and innovative, individual and global, rational and irrational, dogmatic and pluralistic attitudes.

Anthroponyms inexplicably combine voluntaristic and bureaucratic features: a Moscow resident, for instance, received an international passport issued by the World civil society organisation without a Russian birth certificate and Russian citizenship because of the registry office's refusal to register the name BOCh rVF 260602. In terms of the integration space globalisation that unites humanity into a single whole, there is a need for conceptually new approaches to anthroponymic studies.

\section{Conclusion}

The underlying property of the scope of first names is neology, which comes out in simultaneously existing groups of anthroponyms of different neologization degrees.

The heterogeneous character of the contemporary scope of first names both for men and women should be highlighted. Heterogeneity expresses the nominator's identity, who, in many cases, is willing to break from the tradition to name the child after his parents. Today, in the period of globalisation and significant impact of mass culture on people's daily lives, every member of society faces the question: to accept or reject (and to what extent) the proposed phenomena, facts, values. World processes lead to cultural homogeneity and change of social guidelines that force everyone to correct the system of values, identifying what is typical for them and what is not at a given life stage. Thus, to respond to current challenges, onomastics has to study processes that affect the basis of human existence in the modern world, among which identification and identity issues are significant.

The obtained data confirm that there is no robust and direct connection between the ethnic characteristics of the first name and the nominator's ethnic identity. Naming as an element of ethnic identity is recognised only in some cultural environment with familiar characteristics; in another cultural environment an anthroponym may not be recognised as a significant feature, but remains a component of individual identity. The person learns new grounds for his identity through new names and names enrich the developed worldview.

\section{References}

Aceto, M. (2002). Ethnic personal names and multiple identities in Anglophone Caribbean speech communities in Latin America. Language in Society, 31, 577-608.

Aznabaeva, A.F. (2006). Comparative onomastics: naming contemporary in Bashkortostan and in Germany (pp. 122). Ufa.

Bailey, B., \& Lie S. (2017). The power of names in a Chinese Indonesian family's negotiations of politics, culture, and identities. Journal of International and Intercultural Communication, 10(1).

Deutscher, G. (2010). Through the language glass: Why the world looks different in other languages (pp. 304). New York: Metropolitan Books/Henry Holt \& Company.

From the most unusual to the rarest: what names are chosen by the kids parents in Bashkortostan. Available at: http://voshod- 
news.ru/news/9477-ot-samyh-neobychnyh-dosamyh-redkih-kakie-imena-vybirayutmalysham-roditeli-v-bashkirii.html (date accessed 08.11.2018/).

Gaddis, S.M. (2017). How Black Are Lakisha and Jamal? Racial Perceptions from Names Used in Correspondence Audit Studies. Sociological Science.

Galiullina, G.R. (2002). Representation of linguistic and cultural traditions in the modern anthroponymic system of Tatars. Bulletin of Leningrad state university, 2, 78-86.

Gerhards, J. (2005). The Name Game: Cultural Modernization and First Names (pp. 150). J. Gerhards. NY: Transaction Publishers.

Gerritzen, D. (2006). Naming children in a globalizing world. Acta Onomastica, XLVII, 177184.

Golomidova, M.V. (2005). Russian anthroponomical system at the turn of the century. Issues of onomastics, 2, 12-22.

Hofmann, B., \& Mueller, M. (2016), Performing Ethnicity. Performing Gender (pp. 256). New York Routledge.

Kandt, J., \& Longley, P.A. (2018). Ethnicity estimation using family naming practices. PLOSONE, 8.

Labashchuk, M. (2015). The development of anthropocentric theories in modern linguistics. Studia z Filologii polskiej, slowianskiej, 50, 249269.

Lieberson, S., \& Bell, E.O. (1992). Children's First Names: An Empirical Study of Social Taste.

American Journal of Sociology, 98(3), 511-554.

Luján-García, C. (2015). Foreign given names in Spanish youth: evidence of a globalized society. Linguistica Pragensia, 25(2), 145-167.

Mateos, P. (2007). A Review of Name-Based Ethnicity Classification methods and their Potential in Population Studies. Population Space and Place, 13, 145-152.

Mateos, P. (2014). Names, Ethnicity and Populations. Tracing Identity in space, XX, 269.
Muryasov, R.Z. (2006). Are we on the threshold of a new understanding of the essence of language? (pp. 821). Moscow, New York.

Pustyakov, A.A. (2017). Adaptation of Russian orthodox names in the Mari language. Issues of onomastics, 14(3), 128-167.

Risager, K. (2006). Language and culture. Global flows and local complexity (pp. 185199). Clevedon: Multilingual Matters.

Shenkao, G.Kh. (2002). Name as a socio-cultural phenomenon: thesis for a doctoral degree in psychology (pp. 369). Cherkessk.

Shkuropatskaya, M.T., \& Davaa, U. (2016). National linguistic picture of the world as a component of linguistic consciousness of Russian and Mongolian linguistic personality (comparative aspect). Bulletin of Tomsk state university. Philology, 1 (39), 86-95.

Shcherbak, A.S. (2014). The dialect onomastics in the traditional and cognitive aspects. Issues of cognitive linguistics, 4(41), 18-22.

Shcherbak, A.S. (2016). Cognitive specific of urban onyms. Issues of cognitive linguistics, 4 (49), 110-113.

Suleymanova, R.A. (2013). Bashkir-Russian dictionary of personal names and surnames (pp. 364). Ufa: EL UNTS Publ., Russian academy of sciences.

Superanskaya, A.V. (2006). Dictionary of Russian personal names (pp. 544). Eksmo Publ. Series of Library of dictionaries of the Russian academy of sciences.

Tarasov, D.Ya. (2007). Socio-philosophical analysis of the phenomenon of the name in Russian culture: thesis for a candidate degree in philology (pp. 150). Tver'.

Timirkhanov, V.R. (2006). Anthroponymic study of village Ul'kundi, Duvanskiy district of the Republic of Bashkortostan. Onomastics of the Volga region. Proceedings of the $10^{\text {th }}$ international conerence (pp. 169-173). Ufa. Publishing house of Bashkir state pedagogical university. 
Tupeev, S.Kh. (2010). The dictionary of personal names of the Bashkir (Bashkir and Russian) (pp. 360). Ufa. Bashkirskaya entsiklopediya Publ.

Virgilio, M. (2002). La traducción de los nombres propios. Cátedra (pp. 223). Madrid.
Wierzbicka, A. (2012). Understanding others requires shared concepts. Pragmatics and Cognition, 20(2), 356-379. 